\title{
Comparison of E-commerce Regulations in Chinese and American FTAs: Converging Approaches, Diverging Contents, and Polycentric Directions?
}

\author{
Jie (Jeanne) Huang*1
}

\begin{abstract}
Insufficient WTO regulation of cross-border e-commerce confronts China and the US with three legal challenges: ambiguous classification of digital products, inadequate consumer and privacy protection, and weak protection of cross-border flow of information. China and the US have adopted converging approaches to address these challenges: inserting e-commerce chapters into their FTAs. However, the substance of these chapters is diverging. Firstly, US FTAs categorise digital products separately from goods and services and provide national treatment and most favoured nation treatment to products and their suppliers. China's FTAs still offer no solutions to the classification of digital products and their treatment. Secondly, although China's FTAs still provide weak protection for consumers and privacy, Chinese domestic law has converged towards U.S. FTAs to provide better protection. Thirdly, U.S. and China FTAs are significantly divergent in their regulation of the free flow of information. In the post-TPP era, a polycentric direction will emerge in the regulation of the free flow of information between China and the U.S.
\end{abstract}

Keywords $\quad$ E-commerce $\bullet$ Digital Product $\bullet$ China, the United States $\bullet$ Free trade agreement $($ FTA $\bullet$ Free Flow of Information

\section{$1 \quad$ Introduction}

$40 \%$ of Internet users worldwide have purchased products or goods online via desktop, mobile, tablet or other devices. ${ }^{1}$ This amounts to more than 1 billion online consumers and the number is projected to grow. ${ }^{2}$ E-commerce ${ }^{3}$ is a booming market for both China and the U.S. ${ }^{4}$ In 2015, e-commerce represented 7.05\% of China's Gross Domestic Product ("GDP") and $3.32 \%$ of the US' GDP. ${ }^{5}$ China's internet penetration rate was only $51 \%$ in 2015 , with

\footnotetext{
${ }^{*} \bowtie \quad$ Jie (Jeanne) Huang

Jeanne.huang@unsw.edu.au
}

1 Senior Lecturer, Member of China International Business and Economic Law Initiative, University of New South Wales Faculty of Law, Sydney, Australia. This paper is made possible partly through the China National Social Science Fund Project (16BFX202).

${ }^{1}$ Statistics and Market Data about E-commerce, https://www.statista.com/markets/413/e-commerce/ (accessed 10 March 2017).

${ }^{2}$ Ibid.

${ }^{3}$ In this Paper, "e-commerce" is defined as the production, distribution, marketing, sale or delivery of goods and services by electronic means. WTO Work Programme on Electronic Commerce, adopted by the General Council on 25 September 1998, WT/L/274.

${ }^{4}$ More information about e-commerce in the U.S. and China economy and the development trend, see E-Stats 2014 Report: Measuring the Electronic Economy, https://www.census.gov/newsroom/pressreleases/2016/cb16-tps108.html and China E-commerce Report, http://dzsws.mofcom.gov.cn/article/ztxx/ndbg/ (accessed 10 March 2017).

${ }^{5} 2015$ Key B2C E-commerce Data of Goods \& Services at a Glance, page 15, https://www.ecommercewiki.org/wikis/www.ecommercewiki.org/images/5/56/Global_B2C Ecomme rce Report 2016.pdf (accessed 10 March 2017). 
significant growth potential, ${ }^{6}$ thus China has a strong interest in influencing the development of international trade law for e-commerce. On 23 January 2017, the U.S. withdrew from the Trans-Pacific Partnership ("TPP"), a 12-country free trade agreement ("FTA") aiming to establish $21^{\text {st }}$ century standards for international trade, including e-commerce, in the AsiaPacific. ${ }^{7} \mathrm{CNN}$, Bloomberg and the BBC predicted that China may fill the void left by the U.S. to shape international trade law. ${ }^{8}$

In this context, it is necessary to explore the development of international trade law for e-commerce in China and the US in the post-TPP era. However, there is little contemporary scholarship comparing Chinese and American cross-border e-commerce regulations, ${ }^{9}$ and the future development of these laws. This paper answers these questions by examining Chinese and American FTAs, especially the China-Australia FTA, ${ }^{10}$ the ChinaSouth Korea FTA, ${ }^{11}$ the U.S.-Australia FTA, ${ }^{12}$ the U.S.-South Korea FTA ${ }^{13}$ and the TPP.

This paper contains four sections. In Section One, it argues that China and the U.S. are both confronted with three legal challenges brought by booming international trade in ecommerce. This forms the comparative-law backdrop for outlining how Chinese and American FTAs can tackle these challenges. In Section Two, this paper uses historical surveys of FTAs concluded by China and the U.S. to find that there appears to be a convergent approach in addressing these challenges, which is to go beyond the World Trade Organization ("WTO") multilateral framework and adopt a chapter specialising in ecommerce in FTAs. Section Three argues that, although there are substantive similarities, the contents of American and Chinese e-commerce chapters are diverging. Section Four concludes that in the future the diverging trend between Chinese and American FTAs will continue in regulations for cross-border flow of information but may gradually diminish in other fields. However, the U.S. withdrawing from the TPP may enable China to further

\footnotetext{
${ }^{6}$ Ibid, at 16.

${ }^{7}$ U.S. Exit from TPP may open the door to China, https://www.rt.com/business/374925-china-tpp-ustrump-australia/ (accessed 10 March 2017). Simões (2017), p. 165-66, who argues that the TPP is a " $21^{\text {st }}$ century agreement" and potentially set forward a model for FTAs worldwide; Kelsey (2013), p. 241, who states that the TPP is a "gold standard" for the twenty-first centry; Lewis (2011), p. 32-33, who indicates the TPP aims to serve as a model for a broader APEC-wide agreement.

${ }^{8}$ E.g., Jeffrey H Bergstrand, Killing TPP is Bad News for Americans, but Great for China, http://edition.cnn.com/2017/01/23/opinions/killing-ttp-great-for-china-bergstrand-opinion/ (accessed 10 March 2017); TPP: Why the U.S. Withdrawal Could be a Boon for China, http://knowledge.wharton.upenn.edu/article/trans-pacific-partnership/(accessed 10 March 2017); Sink et al. (2017); Gracie (2017).

${ }^{9}$ Regarding comparative studies between China and the U.S., see e.g. Shackelford and Craig (2014), p. 157-64, who compare China, the EU, India, the UK and the U.S. and argue that there exists a continuum of governmental interest in and approaches to regulating cyberspace; Delimatsis (2011), p. 257-293. Regarding discussions on Chinese law for E-commerce, see e.g. Luo (2016), p. 219-228, who provides a general view of China's E-commerce laws and the practices; Yan (2005), p. 6-10. Regarding discussions on U.S. law for E-commerce, see e.g. King and Raja (2013), p. 413-482; Carey (2014), p. 156-271.

${ }^{10}$ The China-Australia FTA took effect on December 20, 2015, for more information, see http://fta.mofcom.gov.cn/topic/enaustralia.shtml (accessed 10 March 2017).

${ }^{11}$ The China-South Korea FTA took effect on December 20, 2015, for more information, see http://fta.mofcom.gov.cn/topic/enkorea.shtml (accessed 10 March 2017).

12 The U.S.-Australia FTA took effect on January 1, 2005, for more information, see https://ustr.gov/trade-agreements/free-trade-agreements/australian-fta (accessed 10 March 2017).

${ }^{13}$ The U.S.-South Korea FTA took effect on March 15, 2012, https://ustr.gov/trade-agreements/freetrade-agreements/korus-fta (accessed 10 March 2017).
} 
influence international law-making for e-commerce. As a result, e-commerce regulations in the Asia-Pacific will develop in a polycentric pattern.

\section{Common Challenges to China and the U.S.}

China and the U.S. are both confronted with three legal challenges brought by international e-commerce: ambiguous classification of digital products, insufficient consumer and privacy protection, and weak protection of cross-border flow of information.

\subsection{Ambiguous Classification of Digital Products}

When the WTO was established, e-commerce was still in its infancy. The WTO divides trade into trade in goods, services, and intellectual property and regulates them accordingly. Neither the General Agreement on Tariffs and Trade ("GATT") nor the General Agreement on Trade in Services ("GATS") defines "e-commerce" or "digital products", thus their classification is unclear. ${ }^{14}$ Classification is complex because three modes of digital products exist. The first mode is essentially traditional goods, which are tangible and physical. Examples include computers, telecommunication equipment, semiconductors, semiconductor manufacturing and testing equipment, scientific instruments and their parts and accessories. The second mode of digital products have physical carriers but their monetary value derives mainly from encoded content, such as CDs, DVDs and software in physical support, while the value of the carrier is minimal. Nowadays $97 \%$ of the first and second mode of digital products is covered by the Information Technology Agreement ("ITA"), a multilateral agreement under the WTO framework. ${ }^{15}$ The ITA classifies the first and second modes of digital products as goods, to which custom duties and non-tariff barriers apply. ${ }^{16}$ The ITA obliges member states to abolish all custom duties on covered products and components, aiming to eliminate non-tariff barriers in trade. ${ }^{17}$ Both China and the U.S. are member states to the ITA. ${ }^{18}$ The expansion of the ITA in 2015 is a landmark achievement of the WTO negotiations, ${ }^{19}$ but it does not regulate the third mode of digital products. The third mode has no physical carrier and is completely transmitted online. ${ }^{20}$ For example, e-books, downloaded or streamed movies, and the Apple Pay service. The monetary value of the products derives solely from their contents. Compared with the first two modes, the third mode is the most significant, due to its industrial usage in cloud computing, big data analytics, the Internet of Things, 3D printing, blockchain technology, etc. Regardless of their usage, digital products in this third mode are essentially cross-border flow of information (or

\footnotetext{
${ }^{14}$ Weber (2015), p. 324.

${ }^{15} 15$ Years of the Information Technology Agreement: Trade, Innovation and Global Production Networks, page 2 https://www.wto.org/english/res_e/publications_e/ita15years_2012full_e.pdf (accessed 10 March 2017). Map of ITA participants, https://www.wto.org/english/tratop_e/inftec_e/ita_map e.htm (accessed 10 March 2017).

${ }^{16}$ See Qi (2016), p. 263-273, who provides suggestions on the balance and harmonization of the tax burden between E-commerce and non-E-commerce enterprises in China.

${ }^{17}$ Ministerial Declaration on Trade in Information Technology Products, WT/MIN (96)/16 (Dec. 13, 1996).

${ }^{18}$ Information Technology Agreement-An Explanation, https://www.wto.org/english/tratop e/inftec e/itaintro_e.htm (accessed 10 March 2017).

${ }^{19}$ WTO, Information Technology Agreement: WTO Members Reach Landmark \$1.3 Trillion IT Trade Deal, WTO, 4 July 2015, https://www.wto.org/english/news_e/news15_e/ita_23jul15_e.htm (accessed 10 March 2017).

${ }^{20}$ The third mode of e-commerce is the trade in digital products defined in the TPP, see art. 14.1 of the TPP.
} 
in other words "data"). The ITA liberalises trade mainly by decreasing tariffs and non-tariff measures, which renders little protection to cross-border flow of information.

WTO case law classifies certain digital products delivered electronically as cross border supply under Article 1.2(a) of the GATS. In Mexico-Telecoms, the WTO panel defined certain public telecommunications services, including circuit switched data transmissions, fax and voice telephony, as cross border supply. ${ }^{21}$ U.S.-Gambling is concerned with a U.S. measure that prohibited the cross-border supply of (Internet) gambling and betting services. ${ }^{22}$ The Appellate Body ("AB") found that electronic gambling services (online or via telephone) fell within the scope of cross-border supply and thus the U.S. measure violated the requirement of full market access in the gambling and betting sector mandated by the U.S. Schedule of Specific Commitments ("W/120"). ${ }^{23}$ However, the AB ruled that the measure was provisionally justified under Article XIV(a) of GATS for the protection of "public morals." 24 China-Audiovisual Products confirmed GATS could be applied to electronic publications, sound recordings and films for theatrical release and distribution. ${ }^{25}$ Both the Panel and the AB held that China's commitments on "sound recording distribution services" in its W/120 extended to distribution of sound recordings through electronic means. ${ }^{26}$ However, these cases do not resolve the classification issue in the WTO framework. Firstly, they are specific to certain digital products and member states. They are not binding on member states which are not parties to these cases. Secondly, neither the Panel nor the AB provide a general definition of digital products or develop a widely applicable rule for their classification in future cases. Thirdly and most importantly, W/120 adopts a positive-list approach, meaning foreign suppliers enjoy market access and national treatment only in the sectors listed in W/120. ${ }^{27}$ Industries that are not listed are presumably not open to foreign suppliers. ${ }^{28}$ Therefore, it is controversial whether new industries such as cloud computing are covered by W/120 or fall outside its coverage as part of the dataprocessing or value-added telecommunication sectors.

\subsection{Insufficient Consumer and Personal Information Protection}

The WTO focuses on market access of industries and non-discriminatory treatment of products, services and their providers, IP rights and the rights holders. ${ }^{29}$ Underlying policies of trade liberalization promote comparative advantages of industries and manufacturers in member states, ultimately providing cheaper and better goods and services, guaranteeing lower risk of shortages and improving consumer welfare. ${ }^{30}$ Although the WTO has labelling requirements and rules on sanitary and phytosanitary measures which address consumer concerns about product safety, ${ }^{31}$ the protection of consumers' personal information is an

\footnotetext{
${ }^{21}$ WTO Panel Report, Mexico-Measures Affecting Telecommunications Services (Mexico-Telecoms), WT/DS204/R, adopted 2 April 2004, paras 7.21-24, 7.45.

${ }^{22}$ WTO Appellate Body Report, United States-Measures Affecting the Cross Border Supply of Gambling and Betting Services (U.S.-Gambling), WT/DS285/AB/R, adopted 7 April 2005, para 2.

${ }^{23}$ Ibid., at para 215.

${ }^{24}$ Ibid., at para 373. For comments of this case, see Wunsch-Vincent (2006a), p. 323-55.

${ }^{25}$ WTO Appellate Body Report, China-Measures Affecting Trading Rights and Distribution Services for Certain Publications and Audiovisual Entertainment Products (China-Audiovisual Products), WT/DS363/AB/R, adopted 21 December 2009, para 162-166,

${ }^{26}$ Ibid.

${ }^{27}$ Low and Mattoo (2008).

${ }^{28}$ Ibid.

${ }^{29}$ Jackson (2006), p. 84.

${ }^{30}$ Ibid.

${ }^{31}$ Butcher and Ip (2007), p. 72.
} 
exception rather than an affirmative obligation in WTO law. ${ }^{32}$ Article XIV(c)(i) and (ii) of GATS permits Members to adopt measures preventing deceptive and fraudulent practices and protecting the privacy and confidentiality of individual records, on the condition that the measures are necessary to advance relevant public policy goals and their application is not arbitrary or unjustifiably discriminative. ${ }^{33}$ These exceptions have not sparked much attention in the GATS negotiations or been examined in any WTO cases thus far. ${ }^{34}$

Laws protecting personal information have traditionally been developed in relation to the physical territory of a country. ${ }^{35}$ However the continued development of trade in digital products requires international cooperation and mutual recognition of the importance of protecting consumers and their personal information. ${ }^{36}$ For example, South Korea collected rich big data about the Middle East Respiratory Syndrome ("MERS") during the outbreak in 2015. ${ }^{37}$ The big data included personal information of patients (e.g. ages, travel history before infection and health records), their close contacts (e.g. family members, visitors and healthcare workers) and their medication (e.g. medicine, treatment, operations and results). ${ }^{38}$ The data helped to build a study map about MERS virus transmission and determine the most effective treatment in South Korea. ${ }^{39}$ In combating MERS, the personal information of individual patients was not helpful, but compiling the personal information of 675 patients and 218 health-care workers generated valuable big data. ${ }^{40}$ MERS was first reported in Saudi Arabia in 2012 and spread to countries in and near the Arabian Peninsula before the South Korean outbreak. ${ }^{41}$ The South Korean data collected could have helped the Arab countries combat MERS, however, differing regulations for the sharing of big data and personal information increased the legal uncertainties of the situation and hindered the sharing of the MERS data collected in South Korea with the Arab countries.

\subsection{Weak Protection of Cross-border Flow of Information}

The concept of free flow of information in the trade of digital products has not been clearly defined. A controversial issue is whether it overlaps with freedom of speech in human rights law. In 2016, the U.S. added China's internet controls to its list of trade barriers. ${ }^{42}$ This action apparently adds human rights implications to the free flow of information in the trade of digital products. The free flow of information and freedom of speech can be distinguished in three aspects.

Firstly, free flow of information in the trade of digital products derives from international conventions on cultural diversity and human rights, such as the UNESCO Convention on the Protection and Promotion of the Diversity of Cultural Expressions, ${ }^{43}$ the

\footnotetext{
${ }^{32}$ Sonia (2014), p. 362-63.

${ }^{33}$ GATS art. XIV (c)(i) and (ii). Personal information is a broader concept covering privacy and individual records and accounts.

${ }^{34}$ MacDonald and Streatfeild (2014), p. 638.

${ }^{35}$ Reinsch (2005), p. 168.

${ }^{36}$ Ciocchetti (2007), p. 71.

${ }^{37}$ Seong (2016), p. 328-29.

${ }^{38}$ Cho et al. (2016), p. 994-1001.

${ }^{39}$ Ibid.

${ }^{40}$ Ibid.

${ }^{41}$ About MERS, https://www.cdc.gov/coronavirus/mers/about/index.html (accessed March 10, 2017).

${ }^{42}$ Mozur (2016), who indicates that "[t]he United States argues against overt censorship and policies that block the flow of data across borders. China has been pushing its agenda that each state should have the right to closely control what websites are available within its borders".

${ }^{43}$ Art. 1 of Convention on the Protection and Promotion of the Diversity of Cultural Expressions, adopted at the UNESCO 33rd session in Paris from 3 to 21 October 2005 (providing freedom of
} 
International Covenant on Civil and Political Rights, ${ }^{44}$ and the recent United Nations human rights reports. ${ }^{45}$ Although these conventions empower people to freely seek, receive and impart information and ideas through any medium, ${ }^{46}$ they lack a strong enforcement mechanism to ensure compliance. ${ }^{47}$ Moreover, unlike freedom of speech, the free flow of information has a unique technological core, consisting of data technologies and services for the collection, processing or storage of data (e.g. cloud computing, big data, the Internet of Things). ${ }^{48}$ These are the essential factors of making information flow in the new era of digitalisation. ${ }^{49}$ Further, free flow of information extends beyond human-to-human and human-to-machine transmission of information to machine-to-machine information flow, which is generally not covered by freedom of speech.

Secondly, cross-border flow of information is related to, but not the same as, access to information. Access to information originates from the citizen-state relationship in a domestic context and its purpose is to prevent abuse of government power, for example, citizens should have right to access governmental information. ${ }^{50}$ However, cross-border flow of information, as its name indicates, has a transnational nature. ${ }^{51}$ In the international trade context, it advocates for Internet Service Providers ("ISPs") to have non-discriminated access to a foreign market.

Thirdly, free flow of information in the trade of digital products goes beyond the public law domain to involve private laws, such as contracts. For example, cross-border trade in digital products permits private entities to make agreements regarding digital authentication and signature. ${ }^{52}$ Private contracting is a useful way to address the differences between domestic law on digital signature and authentication. Private parties may agree upon specific terms and conditions regarding signatures and authentication for cross-border ecommerce transactions. ${ }^{53}$ Parties may mutually determine the appropriate authentication methods for that transaction, and have the opportunity to establish before judicial or administrative authorities that their transaction complies with any legal requirements with respect to authentication. ${ }^{54}$ Party autonomy is also supported by the United Nations

expression in cultural diversity contexts). For comments, see Bernier (2004), p. 65-76; Voon (2006), p. 635-652; Burri-Nenova (2010), p. 51.

${ }^{44}$ Art. 19 of International Covenant on Civil and Political Rights, opened for signature Dec. 19, 2966, 999 U.N.T.S. 171, entered into force Mar. 23, 1976 (providing "freedom to seek, receive and impart information and ideas of all kinds, regardless of frontiers, either orally, in writing or in print, in the form of art, or through any other media of his choice").

${ }^{45}$ E.g. Special Rapporteur on the Promotion and Protection of the Right to Freedom of Opinion and Expression, Promotion and Protection of the Right to Freedom of Opinion and Expression, transmitted by Note of the Secretary-General, U.N.Doc. A/66/290 (Aug. 10, 2011); Special Rapporteur on the Promotion and Protection of the Right to Freedom of Opinion and Expression, Rep. of the Special Rapporteur on the Promotion and Protection of the Right to Freedom of Opinion and Expression, Frank La Rue, Human Rights Council, U.N. Doc. A/HRC/14/23 (Apr. 20, 2010).

${ }^{46}$ Art. 19.2 of the International Covenant on Civil and Political Rights. For comments, see Land (2013), p. 401, who argues international law of the Internet can develop based upon art. 19.2.

${ }^{47}$ Zheng (2013), p. 37-41.

${ }^{48}$ For more information about technology core of free flow of information, see http://netfutures2016.eu/programme/free-flow-of-data/ (accessed 22 May 2017).

${ }^{49}$ Ibid.

${ }^{50}$ See generally Thurman (1973).

${ }^{51}$ Bieron and Ahmed (2012), p. 556.

${ }^{52}$ Art. 14.6 of the TPP, art. 12.6 of the China-Australia FTA and art. 13.4 of the China-South Korea FTA.

${ }^{53}$ E.g., art. 12.6 of the China-Australia FTA.

${ }^{54}$ Ibid. 
Commission on International Trade Law ("UNCITRAL") Model Law on E-commerce. ${ }^{55}$ In addition, industrial self-regulation and industry-led development of e-commerce regulations are also indispensable for the development of trade in digital products. These are not contained in the concept of freedom of speech.

\section{Converging Approaches}

The U.S. began incorporating e-commerce regulations into their FTAs before China. In 2001, the U.S.-Jordan FTA was the first U.S. FTA to include an e-commerce clause. ${ }^{56}$ It requires member states to refrain from imposing customs duties and unnecessary barriers on electronic transmissions, including digitised products. ${ }^{57}$ In 2004, the U.S. concluded the U.S.Singapore and the U.S.-Chile FTAs, which both designate an entire chapter to e-commerce regulation. Compared to the U.S.-Jordan FTA, the U.S.-Singapore and U.S.-Chile FTAs impose a greater number of stronger obligations upon the party states. For example, they require non-discriminatory treatment for digital products and ban customs duties. ${ }^{58}$ The 2005 U.S.-Australia FTA further extends regulations to authentication and digital certificates, ${ }^{59}$ and also provides best-effort clauses for online consumer protection ${ }^{60}$ and paperless trade administration. ${ }^{61}$ The U.S.-Australia FTA is the first to regulate consumer protection in its ecommerce chapter. ${ }^{62}$ Its e-commerce regulations are adopted by the 2009 U.S.-Peru FTA. ${ }^{63}$ The 2012 U.S.-South Korea FTA takes further steps, creating principles on access to and use of the Internet for e-commerce and cross-border information flow. ${ }^{64}$ This is significant because it makes free flow of online information a highlight of the e-commerce chapter.

China only began to use FTAs to regulate e-commerce in 2006. The inaugural ChinaNew Zealand FTA contains an Annex on the "Cooperation in the Field of Conformity Assessment in Relation to Electrical and Electronic Equipment", which aims to reduce technical barriers to trade in electrical and electronic equipment. From 2006 to 2014, China concluded six FTAs, none of which have annexes, clauses or chapters devoted to ecommerce. ${ }^{65}$ These FTAs follow WTO norms and regulate e-commerce through a W/120. The breakthrough came in 2015 with the China-Australia and China-South Korea FTAs, which both contain a chapter designated to e-commerce. China will likely continue to use its FTAs to regulate cross-border e-commerce. There are three main reasons that China may adopt the "chapter" format to regulate e-commerce, particularly when negotiating with developed countries.

Firstly, international law-making for e-commerce is ongoing ${ }^{66}$ and China wants to exert its influence. In 2016, China and Pakistan introduced a proposal to the WTO Council for Trade in Goods and suggested that discussions should focus on the promotion and

\footnotetext{
${ }^{55}$ Art. 4 of the UNCITRAL Model Law on E-commerce (providing that private parties can use consensus to revise the Chapter III Communication of Data Messages).

${ }^{56}$ Art. 7 of the U.S.-Jordan FTA.

${ }^{57}$ Ibid.

${ }^{58}$ Arts 15.3 and 15.4 of the U.S.-Chile FTA and art. 14.3 of the U.S.-Singapore FTA.

${ }^{59}$ Art. 16.5 of the U.S.-Australia FTA.

${ }^{60}$ Ibid., art. 16.6.

${ }^{61}$ Ibid., art. 16.7.

${ }^{62}$ Art. 16.6 of the U.S.-Australia FTA.

${ }^{63}$ Art. 15.5 of the U.S.-Peru FTA.

${ }^{64}$ Arts. 15.7 and 15.8 of the U.S.-South Korea FTA.

${ }^{65}$ The six FTAs are the China-Switzerland FTA, the China-Iceland FTA, China-Costa Rica FTA, China-Peru FTA, China-Chile FTA, and China-Pakistan FTA, for more information see http://fta.mofcom.gov.cn/english/index.shtml (accessed March 12, 2017).

${ }^{66}$ Wunsch-Vincent (2006b), p. 3.
} 
facilitation of cross-border trade in goods enabled by the Internet. ${ }^{67}$ However, they said that discussions should not lead to new market access commitments and"easy issues" should receive priority to achive "pragmatic progress" at the $11^{\text {th }}$ Ministerial Conference ("MC11") in December 2017. In March 2017, China and Pakistan co-sponsored another proposal on ecommerce to the WTO Committee on Trade and Development. ${ }^{68}$ This proposal, again, emphasized ongoing dicussions should primarily addressed the promotion and facilitation of cross-border trade in goods, payments and logistics services. However, although China and some other delgations want to realize some progress by MC11, others do not share this view and hope to continue the exploratory nature of the WTO e-commerce work programme. ${ }^{69}$ Therefore, it is still early to predict whether MC11 can achive "pragmatic progress". Moreover, the Trade in Services Agreement ("TiSA"), currently negotiated under the plurilateral system under the WTO, aims to cover trade in digital products. However, the TiSA negotiation is still at the early stage and China is not a party to the negotiation. Therefore, China needs an international legal framework beyond the WTO to avoid marginalization. FTAs serve this purpose.

Secondly, the robust overseas expansion of Chinese e-commerce companies encourages the Chinese government to incorporate e-commerce protection and promotion into its FTAs. National treatment and market access under the FTAs help maintain the ecommerce companies' continuous development. Chinese e-commerce companies are burgeoning and some (e.g. Baidu, Alibaba, and Tencent) have become nationalistic. ${ }^{70}$ For example, in 2016, retailers on the platform of Alibaba, made $\$ 17.79$ billion worth of gross merchandise revenue on one day (Singles' Day, November 11). ${ }^{71}$ This completely eclipses the $\$ 2.74$ billion and $\$ 3.07$ billion generated online during the Black Friday and Cyber Monday sales respectively in the U.S. in the same year. ${ }^{72}$ Modern electronically transmitted digital products have challenged the categorises in the W/120, which may become a barrier for Chinese e-commerce companies to access foreign markets. For example, the computerrelated services in the W/120 cover five categories: consultancy services related to the installation of computer hardware (841), software implementation services (842, with further five sub-categories), data processing services (843, with further four sub-categories), database services (844) and other services (845 and 849). WeChat, the Chinese smartphone and computer-based instant messaging software with texting, audio, video, payment, call, map and other functions, is considered more successful than Twitter and Facebook by many international IT commentators. ${ }^{73}$ Does WeChat fall into software implementation services or

\footnotetext{
${ }^{67}$ Proposal for e-commerce Discussions Draws Interest, https://www.wto.org/english/news_e/news16 e/good_17nov16 e.htm (accessed 15 July 2017).

${ }^{68}$ WTO Members Discuss the Role of E-commerce in Fostering Development, https://www.wto.org/english/news e/news17 e/devel_14mar17_e.htm (accessed 15 July 2017).

${ }^{69}$ ITEM 6-Work Programme on Electronic Commerce-Review or Progress, Report by the Chairman, General Council Dec 7, 2016 (16-6724).

${ }^{70}$ E.g., Alibaba Cloud expands data centres as it steps up challenge to Amazon, Microsoft, http://www.scmp.com/tech/china-tech/article/2048204/alibaba-cloud-expands-data-centres-it-stepschallenge-amazon (accessed 28 November 2016).

${ }^{71}$ Alibaba Smashes its Sales Record on Singles' Day, but Growth is Slowing, https://techcrunch.com/2016/11/11/alibaba-singles-day-2016/ (accessed 30 November 2016).

${ }_{72}$ Ming (2016). McCauley (2016).

${ }^{73}$ Why Wechat (Not Twitter) Represents the Next Generation of Social Networks, http://www.socialmediatoday.com/content/why-wechat-not-twitter-represents-next-generation-socialnetworks, (accessed 28 November 2016). It's Time for Facebook to Copy Wechat, http://www.forbes.com/sites/helenwang/2016/08/11/its-time-for-facebook-to-copywechat/\#3a4dcf4027a4 (accessed 28 November 2016).
} 
data processing services? Or should it be categorised as telecommunication or financial services? Clarifying these questions benefits Chinese e-commerce companies.

Thirdly, compared with other formats, an e-commerce chapter in an FTA enables China and its contracting state party to make fully-fledged e-commerce regulations. The chapter approach is better because it avoids the classification difficulty and helps to establish a legal system for e-commerce independent from trade in goods, services and intellectual properties ("IP"). Compared with chapters, annexes are often used for explanation and only touch upon regulations in a narrow field, and clauses may not establish a systematic ecommerce legal framework.

\section{Diverging Contents}

Although both China and the U.S. resort to FTAs and adopt the "chapter" format as a solution to the three challenges, the survey of the current FTAs concluded by the U.S. and China shows that the substance of their solutions is diverging.

\subsection{Classification of Digital Products and Their Treatment}

U.S. FTAs create a category separate from goods, services and IP for digital products and offers national treatment and most favoured nation ("MFN") treatment of products and their suppliers. ${ }^{74}$ The TPP even narrows down the definition of digital products to those transmitted electronically. ${ }^{75}$

In contrast, China's FTAs neither define digital products nor contain provisions of national treatment and MFN treatment. This is because China's FTAs only recently began to use the "chapter" format to regulate e-commerce in 2015 and thus have not formed an affirmatory view on how to deal with classification and treatment of digital products. Moreover, most of the digital products sold by top Chinese e-commerce enterprises (e.g. Alibaba and JD) are those with physical carriers. ${ }^{76}$ Therefore, Chinese law-makers may not feel the need to develop specific regulations for digital products transmitted electronically at this current stage.

\subsubsection{Classification}

In contrast to the WTO dichotomy of trade in goods and trade in services, the TPP creates a new category for digital products. It excludes digitally encoded contents, fixed on a carrier medium, from the scope of digital products. ${ }^{77}$ This definition departs from previous FTAs concluded by the U.S., which do characterize contents fixed on a carrier medium digital products, as seen in Article 16.8.4 of the U.S.-Australia FTA, Article 15.8 of the U.S.Peru FTA and Article 15.9 of the U.S.-Korea FTA. In these FTAs, "carrier medium" is defined as any existing or later developed physical object capable of storing a digital product, and from which a digital product can be perceived, reproduced, or communicated, directly or indirectly. ${ }^{78}$ The physical object may be an optical medium, floppy disk, magnetic tape, etc. ${ }^{79}$ The TPP excludes digital products fixed on carrier medium from its e-commerce chapter, which helps to classify digital products into a category independent from goods and services.

\footnotetext{
${ }^{74}$ The definition of digital product in the U.S. FTAs does not reflect a party's view on whether trade in digital products through electronic transmission should be categorised as trade in services or trade in goods in the WTO. Footnote 4 of the U.S.-South Korea FTA and Footnote 3 of the TPP.

${ }^{75}$ Art. 14.1 of the TPP.

${ }^{76}$ Introduction to JD, https://www.jd.com/intro/about.aspx (accessed 21 May 2017). Best sellers in Taobao.com, https://top.taobao.com/?spm=a1z5i.1.2.1.hUTg2J\&topId=HOME (accessed 21 May 2017).

${ }^{77}$ Ibid.

${ }^{78}$ See art. 16.8 .4 of the Australia-U.S. FTA.

${ }^{79}$ Ibid.
} 
This is because CDs, DVDs and other content-based products have physical carriers so they can be governed by regulations for trade in goods.

Although a digital product may be neither a good nor a service, it may be affected by investment or service measures. For example, services delivered or performed electronically are subject to regulations of the e-commerce chapter and other FTA chapters. The U.S.-South Korea FTA provides that when regulations overlap, a state's obligations under the ecommerce chapter are subject to regulations under the chapters on investment and crossborder trade in services or financial services. ${ }^{80}$ Where there is conflict, the latter three chapters prevail. ${ }^{81}$ The U.S.-South Korea FTA has Annexes I, II and III listing nonconforming measures in the chapters on investment and cross-border trade in services or financial services, which also apply to e-commerce. ${ }^{82}$ Therefore, obligations such as the nondiscriminatory treatment of digital products, cross-border transfer of information by electronic means, and location of computing facilities are exempted when a non-conforming measure is maintained or adopted according to the three annexes. ${ }^{83}$

Neither the China-Australia FTA nor the China-South Korea FTA defines ecommerce or digital products. The China-South Korea FTA defines "data message" as information generated, sent, received or stored by electronic, optical or similar means. ${ }^{84}$ However, this definition is given in the context of digital signatures. ${ }^{85}$ The future of China's FTAs may deviate from the dichotomy of goods and services under the WTO framework to create a separate category for digital products. Classification is a precondition for proper treatment to digital products. Without resolving classification issues, China cannot determine the proper treatment for digital products, which will hinder the development of Chinese ecommerce regulation. ${ }^{86}$

\subsubsection{Treatment}

Non-discriminatory treatment is foundational to WTO law. However, WTO law does not offer national treatment and MFN treatment to digital products and their suppliers for two reasons. Firstly, MFN is a general obligation in GATT, but it only applies to products and not to product suppliers. ${ }^{87}$ Therefore, if digital products were classified as goods, their suppliers could not enjoy the MFN treatment under WTO law. Secondly, if digital products were classified as services, whether the products and their suppliers could enjoy national treatment in a specific industrial sector depends on whether the sector is listed in the W/120. This is because the national treatment under the GATS is a specific commitment, rather than a general obligation. ${ }^{88}$ Therefore, there is no guarantee that a certain digital product and its supplier can enjoy national treatment under the WTO.

Neither the China-South Korea nor the China-Australia FTA contain a nondiscriminatory treatment clause in their e-commerce chapters. In sharp contrast, the e-

\footnotetext{
${ }^{80}$ Art. 15.2 of the U.S.-South Korea FTA.

${ }^{81}$ Ibid.

${ }^{82}$ Ibid., art. 15.3.4.

${ }^{83}$ Art. 14.5 of the TPP.

${ }^{84}$ Art. 13.8 of the China-South Korea FTA.

${ }^{85}$ Electronic signature is defined as data in electronic form that is in, affixed to, or logically associated with a data message, which may be used to identify the signatory in relation to the data message and to indicate the signatory's approval of the information contained in the data message. See Art. 13.8 of the China-South Korea FTA.

${ }^{86}$ See discussion below in Section II.2.

${ }^{87}$ Art. 1 of the GATT.

${ }^{88}$ Art. XVII of GATS.
} 
commerce chapters in the U.S.-South Korea ${ }^{89}$ and U.S.-Australia ${ }^{90}$ FTAs contain a nondiscriminatory treatment clause.

Because both the U.S.-Australia and U.S.-South Korea FTAs cover digital products with a physical carrier or completely transmitted online, their non-discriminatory clauses apply to digital products stored or transmitted in the territories of both parties. The nondiscriminatory treatment also applies to distributor of the other party. ${ }^{91}$ However, the TPP does not extend national treatment to digital products stored or transmitted in the territory of the other party like it accords to digital products in a country's own territory. This may be explained by the fact that the digital products referred to in the TPP have no physical carrier. Storage and transmission are closely related to physical carriers. For example, it is difficult to determine whether a movie downloaded by an Australian consumer from an American website crossed other countries' servers in the process. However, if a movie is burned on a CD and imported from the U.S. to Australia, it is easier to determine how many countries the CD crossed during transportation. Moreover, the TPP bans localization of computing facilities, making storage a less compelling reason to offer non-discriminatory treatment.

\subsection{Consumer and Personal Information Protection}

Protecting consumer confidence in e-commerce is as important as removing trade barriers. ${ }^{92}$ Among the U.S. FTAs, ${ }^{93}$ the TPP designs the most comprehensive regime of consumer protection. It can be divided into three aspects: combatting fraudulent and deceptive commercial activities, minimising unsolicited commercial spams, and protecting personal information and privacy. ${ }^{94}$

China's FTAs also makes efforts to protect consumers. However, unlike the U.S., China emphasises technology neutrality in consumer protection. China also approaches personal information protection in a different way to the U.S. For example, the ChinaAustralia FTA equalises personal information protection and online data protection, ${ }^{95}$ while online data protection in the TPP focuses on free flow of information. ${ }^{96}$

Although China's FTAs do not regulate internet fraud and commercial spams, these are rampant, urgent issues that damage Chinese consumers' confidence in e-commerce. ${ }^{97}$ Accordingly, the Chinese government has recently taken strong actions to punish internet fraud and deter commercial spams. ${ }^{98}$ A typical example is the newly amended Chinese Law on Protection of the Rights and Interests of Consumers in 2014 ("China Consumer Protection Law"). ${ }^{99}$ Under the Law, when consumers buy goods online, they have the right to return the

\footnotetext{
${ }^{89}$ Arts. 15.3 .2 and 15.3 .3 of the U.S.-South Korea FTA.

${ }^{90}$ Art. 16.4 of the U.S.-Australia FTA.

${ }^{91}$ Ibid.

${ }^{92}$ Art. 14.2 of the TPP.

${ }^{93}$ The e-commerce chapter of the U.S.-Australia FTA, the U.S.-Peru FTA, and the U.S.-South Korea FTA contains a provision for consumer protection.

${ }^{94}$ Ensure easy access to and use of the Internet for e-commerce can also enhance consumer benefits. However, because it is more closely related to free flow of information, this paper will discuss it in below Section III.B.

${ }^{95}$ Art. 12.8 of the China-Australia FTA.

${ }^{96}$ Art. 14.11 of the TPP.

${ }^{97}$ A Survey of Internet Fraud in China, http://news.qq.com/cross/20170309/49rpD72V.html\#0 (accessed 20 May 2017).

${ }^{98}$ Xinhua News Agency: China Continues Enhancing Measures to Combat Internet Fraud, http://www.sina.com.cn/midpage/mobile/index.d.html?docID=fyafcyx6844660\&url=tech.sina.cn/t/20 17-02-03/detail-ifyafcyx6844660.d.html (accessed 20 May 2017).

${ }^{99}$ The Decision on Amending the Chinese Consumer Protection Law was adopted at the 5th Session of the Standing Committee of the Twelfth National People's Congress on October 25, 2013, and took effect on 15 March 2014.
} 
goods within seven days of receipt without needing to give a reason. ${ }^{100}$ This measure may deter fraudulent online retailers peddling low-quality products. The Law also requires online sellers provide consumers with information such as their business addresses, contact methods, the quality and quantity of goods or services, and prices or costs, the duration and manner of performance, safety precautions and risk warnings, after-sales service, and civil liability. ${ }^{101}$ This requirement can help consumers seek legal remedies against online retailers engaging in fraudulent and deceptive commercial activities. Moreover, Chinese

Administrative Measures for Online Trading and China Consumer Protection Law also ban commercial spam sent without consumers' consent or after a clear refusal, ${ }^{102}$ echoing a TPP requirement. ${ }^{103}$ In China, consumers have recourse against commercial spam suppliers. They can bring tort claims if the spam suppliers illegally access their phone numbers or email addresses. ${ }^{104}$ They can allege contractual breach if a telecommunication services provider promises to diminish commercial spams in a service contract but fails to do so. Consumer associations can also bring class actions on behalf of consumers against commercial spam suppliers or telecommunication companies. ${ }^{105}$

Online personal information protection under the China-South Korea and ChinaAustralia FTAs is similar to those in the U.S.-South Korea and U.S.-Australian FTAs, but is much weaker than that of the TPP. ${ }^{106}$ The main reason for this is personal information protection involves behind-the-border measures but Chinese domestic law for personal information protection is still developing, so China has refrained from making any commitments in its FTAs. In China, laws concerning personal information protection are fragmented and most regulations are issued by ministries, rather than from the National People's Congress ("NPC") and its Standing Committee. Although China does not have a comprehensive personal information protection regime, its domestic law has clearly gone beyond the personal information protection requirement in its FTAs. For example, the general requirement is that collection and use of personal information must comply with principles of legality, properness and necessity. ${ }^{107}$ Consumers must be informed about the purpose, method and scope of the information collected and used. ${ }^{108}$ If providing personal information is not a legal obligation, the collection of personal information must be dependent on consumers' consent. ${ }^{109}$ In 2009, the Standing Committee of the NPC criminalised the selling or providing of personal information about any citizen, obtained during the organ's or entity's performance of duties or provision of services, by a staff member of a state organ or an entity in a field such as finance, telecommunications, transportation, education or medical treatments. ${ }^{110} \mathrm{In}$ December 2016, the China Internet Security Law prohibited the collection of personal data

\footnotetext{
${ }^{100}$ Ibid., art. 25, exceptions include made-to-order goods, perishables, digitalized goods which are downloaded or opened by consumers, and delivered newspapers and periodicals.

${ }^{101}$ Ibid., art. 28.

102 Art. 18 of Administrative Measures for Online Trading issued by State Administration for Industry \& Commerce on January 26, 2014. Art. 29 of the China Consumer Protection Law.

${ }^{103}$ Art. 14.14 .1 of the TPP.

${ }^{104}$ Art. 2 of Chinese Tort Liability Law, enacted on 26 December 2009 and effective on 1 July 2010.

${ }^{105}$ Arts. 37.7 and 47 of the China Consumer Protection Law.

${ }^{106}$ Arts. 14.1 and 14.8 of the TPP.

${ }^{107}$ Art. 7.2 of Provisions on the Administration of Mobile Internet Applications Information Services, issued by Cyberspace Administration of China on June 28, 2016.

${ }^{108}$ Ibid., arts. 7.2 and 8 .

${ }^{109}$ Ibid., arts. 7.2 and 7.4.

${ }^{110}$ This person can be sentenced to fixed-term imprisonment not more than three years or criminal detention, and/or be fined. Art. 253 of the Chinese Criminal Law.
} 
without consent and the illegal transfer or sale of personal information to third parties by ISPs and other businesses. ${ }^{111}$

Therefore, although China's FTAs are still weak in protecting consumers and privacy, Chinese domestic law has demonstrated a converging trend with the U.S. FTAs to provide better protection to consumers and their personal information.

\subsection{Free Flow of Information}

Regulations for free flow of information first appear in the U.S.-Korea FTA and are fully developed in the TPP. ${ }^{112}$ China's FTAs have never touched on the free flow of information. Chinese domestic law on the internet aims to control information flow rather than protect netizens' right to access online information. ${ }^{113}$ China is concerned that commitments to free flow of information for e-commerce in the FTAs will ultimately make its internet censorship a trade barrier. Although free flow of information in trade of digital products may not be the same as freedom of speech in human rights law, China worries that the former may potentially be extended to the latter. ${ }^{114}$

\subsubsection{Principles on Access to and Use of the Internet for E-commerce}

Article 14.10 of the TPP provides principles on access to and use of the internet for ecommerce: consumers should be able to benefit from choosing internet services and applications freely, connecting their end-user devices to the internet at will, and having open access to online information. ${ }^{115}$ These principles first appear in the U.S.-South Korea FTA and apply subject to domestic law of a member state. ${ }^{116}$ However, unlike the U.S.-South Korea FTA, the TPP holds these principles subject to undefined "applicable policies, laws and regulations". 117 "Applicable policies, laws and regulations" may include a member's domestic policies, laws and regulations and international standards. ${ }^{118}$ This means members may not justify deviation from these principles based on compliance with domestic law, but should be comply with international laws that encourage free flow of information. Notably, in June 2011, the UN Special Rapporteur on the Promotion and Protection of the Right to Freedom of Opinion and Expression declared that internet access is a human right. ${ }^{119}$ "Cutting off users from internet access, regardless of the justification provided, including on

${ }^{111}$ Arts. 41-45 of the China Internet Security Law, enacted on November 7, 2016 and effective on June 1, 2017.

${ }^{112}$ Art. 15.7 and 15.8 of the U.S.-South Korea FTA and Chapter 14 of the TPP.

${ }^{113}$ Yong (2016), p. 2-3, who argues that “"right-oriented laws' constrains on government powers while 'control-based law' imposes restrictions on citizens."

${ }^{114}$ See Brenkert (2009), p. 454; Roundup: Google Pulls Out of China,

https://www.theguardian.com/media/pda/2010/mar/23/google-china, (accessed March 12, 2017).

115 TPP, art. 14.10.

${ }^{116}$ Art. 15.7 of the U.S.-South Korea FTA. The principles under the U.S.-South Korea FTA are slightly different from the TPP: consumers should be able to (a) access and use services and digital products of their choice, unless prohibited by the Party's law; (b) run applications and services of their choice, subject to the needs of law enforcement; (c) connect their choice of devices to the Internet, provided that such devices do not harm the network and are not prohibited by the Party's law; and (d) have the benefit of competition among network providers, application and service providers and content providers.

${ }^{117}$ Ibid.

${ }^{118}$ Ibid.

${ }^{119}$ Special Rapporteur on the Promotion and Protection of the Right to Freedom of Opinion and Expression, Rep. of the Special Rapporteur on the Promotion and Protection of the Right to Freedom of Opinion and Expression, 4, Human Rights Council, U.N. Doc. A/HRC/17/27 (16 May 2011) (by Frank La Rue) available at http://daccess-ddsny.un.org/doc/UNDOC/GEN/G11/132/01/PDF/G1I113201.pdf?OpenElement (accessed 28 November 2016). 
the grounds of violating intellectual property rights law, to be disproportionate and thus a violation of article 19(3) of the International Covenant of Civil and Political Rights." 120 Therefore, despite these principles still being best-effort endeavours even under the TPP, they are significant because of their potential human rights connotation. This is different from previous U.S. FTAs.

China has never opened the industry of internet access services to foreign investors in its FTAs. It maintains similar restrictions in related areas, such as value-added and basic telecommunications services. ${ }^{121}$ Netizens in China cannot choose internet access service suppliers freely. A recent breakthrough was the 2016 amendment to the Agreement on Trade in Services to the Mainland and Hong Kong/Macao Closer Economic Partnership Arrangement ("CEPA"). ${ }^{122}$ According to this amendment, service providers from Hong Kong and Macao may establish equity joint ventures or wholly-owned enterprises in mainland China to provide internet access services (limited to the internet access services provided for internet users) and online data and transaction processing (limited to for-profit ecommerce). ${ }^{123}$ No limit is set on the proportion of equity held by investors from Hong Kong and Macao in such enterprises. ${ }^{124}$ However, opening the internet access service supplier market in mainland China to investors from Hong Kong and Macao does not necessarily mean China will do the same with foreign investors, because Hong Kong and Macao are considered parts of China.

\subsubsection{Cross-border Transfer of Electronic Information}

Among U.S. FTAs, the U.S.-Korea FTA was the first to protect cross-border online information flow. ${ }^{125}$ Article 14.11 of the TPP imposes a compulsory obligation on its members to enable a covered person to freely transfer information (including personal information) online and cross-border for the conduct of commerce. ${ }^{126}$ It is very difficult for China to make such commitments because China practices sophisticated censorship on the internet. ${ }^{127}$ Its "Great Firewall" filters all online content using different targets, such as internet content providers, individual consumers, and contents on foreign websites. ${ }^{128}$ China maintains its ban on Google, Facebook, Twitter, New York Times and many other websites despite the majority of their content having no relation to Chinese politics. ${ }^{129}$ China is concerned that the commitments to cross-border transfer of electronic information in FTAs may become a Trojan Horse to current censorship, because this freedom has the potential to be extended to the ideological field and may promise rights to political dissidents. ${ }^{130}$

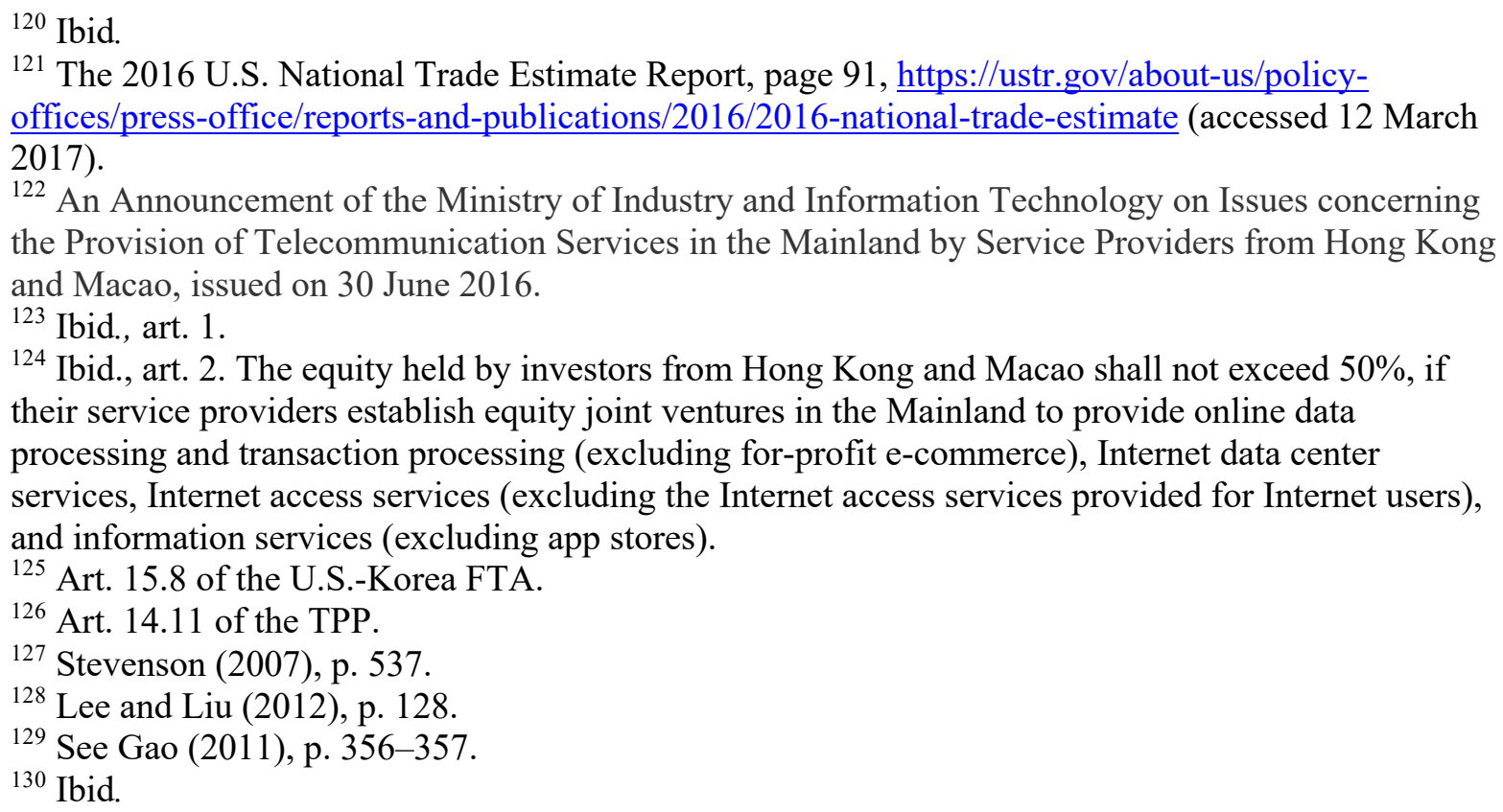


Article 14.11 .3 of the TPP explicitly provides that parties may deviate from free cross-border transfer of electronic information for a legitimate public policy purpose, on the condition that the restrictive measure is proportionate, not arbitrary or unjustifiably discriminatory, and does not function as a disguised restriction on trade. ${ }^{131}$ This clause is more detailed than Article 15.8 of the U.S.-Korea FTA, which provides that "...the Parties shall endeavour to refrain from imposing or maintaining unnecessary barriers to electronic information... (emphasis added)". It is not clear what types of barriers are unnecessary.

Article 14.11.3 of the TPP is similar to Article XX of the GATT 1994 and Article XIV of the GATS (collectively "General Exceptions in the WTO") ${ }^{132}$ because they contain a two-tier test and similar terms.

Firstly, both articles recognise the right of members to adopt measures which would otherwise be inconsistent with their treaty obligations, provided that certain conditions are satisfied. This constitutes a two-tier test: the challenged measure must first fall within the scope of exceptions and then must satisfy the application requirements set out in the articles. This two-tier test has been adopted by several WTO cases, such as U.S.-Gasoline, ECAsbestos, and U.S.-Shrimp. ${ }^{133}$ Article 14.11 .3 of the TPP also requires a two-tiered test. A TPP member must first prove that the non-conforming measure is adopted to protect public policy. Then it must demonstrate that its implementation will not lead to arbitrary or unjustifiable discrimination and it will not function as a disguised restriction on trade or impose restrictions on transfers of information greater than are required to achieve the objective. Notably, the structure of Article 14.11.3 of the TPP is the reversed form of Article XX of the GATT 1994. The former states the exception in its chapeau and the application requirement in its sub-paragraph; in contrast, the chapeau of the latter provides the application requirement, while its sub-paragraph indicates the exceptions. Although the two articles are structured differently, it should not impact the application of the two-tier test.

Secondly, Article 14.11.3 of the TPP and the General Exceptions in the WTO adopt several similar or even identical terms, such as public policy in the TPP and public morals or public order in the WTO, "arbitrary or unjustifiable discrimination" and "disguised restriction" on international trade.

The WTO has a body of rich jurisprudence concerning the meanings of these terms. In U.S.-Gasoline, the AB held that "arbitrary or unjustifiable discrimination" means the application of the non-conforming measure must result in discrimination and the discrimination must be arbitrary or unjustifiable in character. ${ }^{134}$ In Brazil-Retreaded Tyres, the $\mathrm{AB}$ held that the cause or rationale of the discrimination is the focal point for analysing whether the application of a measure results in arbitrary or unjustifiable discrimination. ${ }^{135}$ The effects of discrimination are not determinant. The AB also stated that arbitrary or unjustifiable discrimination exists when the reasons given for the discrimination were not rationally connected to the objective falling within the purview of a paragraph of Article XX, or go against that objective. ${ }^{136}$ In U.S.-Shrimp, the U.S. banned the importation of shrimps or

\footnotetext{
${ }^{131}$ Art. 14.11 .3 of the TPP.

${ }^{132}$ Art. XX of the GATT 1994 and Art. XIV of the GATS.

${ }^{133}$ WTO Appellate Body Report, U.S.-Standards for Reformulated and Conventional Gasoline (U.S.Gasoline), WT/DS2/AB/R, adopted 29 April 1996, para. 22; WTO Panel Report, EC-Measures Affecting Asbestos and Asbestos-Containing Products (EC-Asbestos), WT/DS135/R, adopted 18 September 2000, para. 6.20; WTO Panel Report, U.S.-Import Prohibition of Certain Shrimp and Shrimp Products (U.S.-Shrimp), WT/DS58/R, adopted 15 May 1998, paras. 5.27-5.28.

${ }^{134}$ U.S.-Gasoline, above 133, at para 24.

${ }^{135}$ WTO Appellate Body Report, Brazil-Measures Affecting Imports of Retreaded Tyres (BrazilRetreaded Tyres), WT/DS332/AB/R, adopted 3 December 2007, para 225.

${ }^{136}$ Ibid., paras 226-230.
} 
shrimp products except for those harvested under conditions that do not adversely affect sea turtles or in waters subject to the jurisdiction of a nation certified pursuant to U.S. law. The $\mathrm{AB}$ held that the ban constituted "arbitrary" and "unjustifiable" discrimination because the U.S. failed to engage the WTO members exporting shrimp to the U.S. in serious negotiations with the objective of concluding bilateral or multilateral agreements to protect and conserve sea turtles. ${ }^{137}$ Nevertheless, the requirement for serious negotiation did not require the successful conclusion of an agreement. ${ }^{138}$ The ban lacked flexibility and failed to consider the different situations of various WTO members. ${ }^{139}$

WTO jurisprudence has identified three criteria to determine whether a nonconforming measure is a "disguised restriction on international trade." Firstly, whether the contested measure is published. In U.S.-Gasoline, the $\mathrm{AB}$ held that a restriction in international trade that is concealed or unannounced constituted a "disguised restriction". ${ }^{140}$ Secondly, whether the application of a non-conforming measure is arbitrarily or unjustifiably discriminatory may be taken into account in determining the presence of a "disguised restriction on international trade". ${ }^{141}$ Thirdly, the "design, architecture and revealing structure" of the measure must be examined to discern whether it is intended for protective application. ${ }^{142}$

Notably, WTO jurisprudence has been criticised for enforcing trade rules without acknowledging human rights. ${ }^{143}$ The typical examples are China-IP Rights ${ }^{144}$ and ChinaAudiovisual Products. ${ }^{145}$ China's internet censorship is equally applied to both domestic and foreign ISPs, so it may not violate the national treatment under the WTO. ${ }^{146}$ Its censorship is openly published as law. For example, when an internet information search service provider finds results which contain any information or applications prohibited by any Chinese law or regulation, it will cease the search, retain records and report to the State Internet Information Office or the local internet information office in a timely manner. ${ }^{147}$ Further, the market access obligation under China's W/120 adopts a positive list. The limited commitments that China has made to internet services significantly increase the difficulty of linking international trade law with human rights protection. ${ }^{148}$

Nevertheless, China will wait to see how the exceptions in Article 14.11.3 of the TPP will be interpreted and whether the international commitment to cross-border transfer of electronic information can help remove domestic restrictions on freedom of speech.

\subsubsection{Localisation of Computing Facilities}

Banning localisation of computing facilities is a new clause and has never appeared in U.S. FTAs other than the TPP. TPP members cannot require a covered person to use or locate

\footnotetext{
${ }^{137}$ U.S.-Shrimp, above n 133, paras. 166-172.

${ }^{138}$ Ibid., para. 134.

${ }^{139}$ Ibid.

${ }^{140}$ U.S.-Gasoline, above n 133, para. 25.

${ }^{141}$ Ibid. para. 24.

${ }^{142}$ EC-Asbestos, above n 133, para. 8.236.

${ }^{143}$ Siqueira (2014), pp. 39-60; Wu (2006), p. 280.

${ }^{144}$ WTO Panel Report, China-Measures Affecting the Protection and Enforcement of Intellectual Property Rights (China-IP Rights), WT/DS362/R, adopted 26 January 2009. For comments, see e.g. Broude (2010), p. 661.

${ }^{145}$ China-Audiovisual Products, above n 25. For comments, see e.g. Pauwelyn (2010), p. 132-33; Qin (2011), p. 271.

${ }^{146}$ Siqueira (2014), p. 70, above n 143.

${ }^{147}$ Art. 8 of the Provisions on the Administration of Internet Information Search Services, issued by

State Internet Information Office on 25 June 2016.

${ }^{148}$ See Wu (2006), pp. 281, 283, above n 143.
} 
local computing facilities as a precondition for doing business in its territory. ${ }^{149}$ Banning localisation of computing facilities is a compulsory obligation for TPP members and also subject to the same exceptions as the cross-border transfer of electronic information. ${ }^{150}$

Free cross-border transfer of electronic information focuses on preventing a government from keeping data outside of its border by measures such as censorship. ${ }^{151}$ Industry and internet advocates argue that localisation may pose a more serious threat to the internet than censorship, because it "threatens the major new advances in information technology---not only cloud computing, but also the promise of big data and the Internet of Things." 152

Recently, China has taken steps towards economy-wide requirement of data localisation. ${ }^{153}$ For example, in China, a book, audiovisual, electronic, newspaper or periodical publisher who provides online publishing services must localise its servers and storage devices in China's territory. ${ }^{154}$ In 2013, the Standardisation Administration and the General Administration of Quality Supervision, Inspection, and Quarantine published new national standards that prohibit overseas transfers of data to any entity, absent express user consent, government permission or other explicit legal or regulatory permission. The 2016 China Internet Security Law also requires that personal information and important data collected by key telecommunication infrastructure operators or generated during their operations in China shall be stored in the China territory. ${ }^{155}$ The underlying policies for data localisation are to ease security concerns, combat rampant identity theft and diminish illegal trade in personal data. According to a survey conducted by the European Centre for International Political Economy, localisation may decrease China's GDP by $1.1 \%$ and reduce China's exports by $1.7 \%$ due to loss of competitiveness, create $\$ 63$ bn of welfare losses and lower the average month salary per worker by $13 \% .{ }^{156}$ However, localisation helps ensure data providers' adherence to Chinese law and the government's socialist values. ${ }^{157}$ Chinese courts can exercise personal jurisdiction based on the location of the server. ${ }^{158}$ For the Chinese government, these political and ideological values outweigh the economic costs of data localisation.

\subsubsection{Internet Connection Charge Sharing}

If foreign ISPs have no access to domestic Internet infrastructure, free cross-border flow of information is hard to achieve. ${ }^{159}$ The TPP suggests to its member states to allow a supplier seeking internet connection of a member to negotiate charge sharing with suppliers of other members on a commercial basis. ${ }^{160}$ Notably, this is a best-effort clause. Annex IV

\footnotetext{
${ }^{149}$ Art. 14.13 .2 of the TPP.

${ }^{150}$ Ibid., art. 14.13.3.

${ }^{151}$ See above $\mathrm{n} 143$.

152 Clark and Berners-Lee (2014). Chander (2014).

153 Bauer et al (2014).

${ }^{154}$ Art. 8 of the Provisions on the Administration of Online Publishing Services, issued by Ministry of Industry \& Information Technology and effective on 10 March 2016.

155 Art. 37 of the China Internet Security Law.

${ }^{156}$ Matthias Bauer et al. (2014), p. 2.

157 Art. 3 of the Provisions on the Administration of Online Publishing Services.

${ }^{158}$ Art. 2 of the Supreme People's Court Judicial Interpretation Regarding Applicable Laws to Civil Cases Related to Computer Domain Name Disputes, published on 26 June 2001; art. 25 of Supreme People's Court Judicial Interpretation Regarding Chinese Civil Procedure Law, published on 18 December 2014 and effective on 4 February 2015.

159 See Burri-Nenova (2009), p. 40.

${ }^{160}$ Art. 14.12 of the TPP. Suppliers may negotiate compensation for the establishment, operation and maintenance of facilities.
} 
(non-conforming measures for state-owned enterprises and designated monopolies) of the TPP does not apply to e-commerce. ${ }^{161}$

However, in China, internet connection services are run by wholly state-owned telecommunications service providers and are thus not open to foreign suppliers. ${ }^{162}$ International communications services must be conducted through international communications gateways, the establishment of which must be approved by the Chinese Ministry of Information Industry. ${ }^{163}$ No entity or individual may engage in international communications by any other means. ${ }^{164}$ The country's international network traffic comes in and leaves exclusively through three international internet exits: Beijing (using Qingdao's ocean optic fiber cable), Shanghai and Guangzhou (using Shantou's ocean optic fiber cable). ${ }^{165}$ Up to January 2015, there was a large population of netizens, approximately 649 million in China. ${ }^{166}$ These factors create a veritable bottleneck for international Internet bandwidth, meaning the Internet connection charge is high while speed is low. ${ }^{167}$ In this context, Chinese state-owned internet connection service providers may not have incentives to negotiate on a commercial basis with foreign competitors.

\subsubsection{ISP Safe Harbor}

Free flow of information requires that international trade law provide secondary liability protection for ISPs. The WTO Agreement on Trade-Related Intellectual Property Rights ("TRIPs") does not touch upon this issue. ${ }^{168}$ Starting from the U.S.-Australia FTA, the intellectual property chapters of U.S. FTAs contain provisions to limit liabilities of copyright infringement for ISPs. ${ }^{169}$ This is the so-called ISP safe harbor. ${ }^{170}$ These provisions require member states to provide legal incentives for ISPs to cooperate with copyright owners, to deter the unauthorised storage and transmission of copyrighted materials and limit remedies against ISPs for copyright infringements they do not control, initiate or direct, but that take place through systems or networks controlled or operated by them or on their behalf. ${ }^{171}$ The condition is that the ISPs expeditiously remove or disable access to material residing on their

\footnotetext{
${ }^{161}$ Annex IV of the TPP.

${ }^{162}$ Art. 5 of the Management Procedures for International Communications Gateway Exchanges, enacted on 14 March 2002 and published on 1 October 2002.

${ }^{163}$ Ibid., art. 6.

${ }^{164}$ Ibid.

${ }^{165}$ Zhang (2015).

${ }^{166}$ China Internet Network Information Center (CNNIC), The 35th Report on the Development of the Internet in China, January 2015, http://bit.ly/1MnNKyr (accessed 28 November 2016).

${ }^{167}$ Singapore has World's Fastest Peak Internet Connection Speeds, http://www.scmp.com/tech/social-gadgets/article/1868859/singapore-has-worlds-fastest-peakinternet-connection-speeds-no (indicating "the Chinese mainland ranked at the bottom of the AsiaPacific region in terms of peak connection speeds with a median reading of just $18.4 \mathrm{Mbps}$ and a broadband adoption of 28 per cent."), (accessed 28 November 2016).

168 The TRIPs Agreement is Annex 1C of the Marrakesh Agreement Establishing the Wold Trade Organization, signed in Marrakesh, Morocco on April 15, 1994, https://www.wto.org/english/tratop_e/trips_e/t agm0_e.htm, (accessed 28 November 2016). ${ }^{169}$ Eg., art. 17.29 of the U.S.-Australia FTA, art. 16.9.22 of the U.S.-Singapore FTA, Art. 17.11.23 of the U.S.-Chile FTA, art. 18.9.30 of the U.S.-South Korea FTA, and Section J of Chapter 18 of the TPP. For comments, see Knight (2011), p. 38.

${ }^{170}$ Mishra (2017), pp. 55-56.

${ }^{171}$ Different from other U.S. FTAs listed in footnote 240, the TPP explicitly requires the limitation on remedies shall preclude monetary relief against ISP. Art. 18.82.1 of the TPP.
} 
networks or systems when they become aware of infringement. ${ }^{172}$ This allows ISPs to develop vibrant information online while combating Internet copyright infringement. ${ }^{173}$

The ISP safe harbor has counterparts in Chinese domestic law. ${ }^{174}$ Article 36 of Chinese Tort Law provides that where an Internet user commits a tort using the internet, the victim of the tort shall be entitled to notify the ISP to take such necessary measures as deletion, block or disconnection. ${ }^{175}$ If, after being notified, the ISP fails to take necessary measures in a timely manner, it shall be jointly and severally liable for any additional harm to the internet user. ${ }^{176}$ This is like the safe harbor provisions in the U.S. FTAs. An underlying reason for this similarity is, compared with other components of free flow of information, intellectual property protection has fewer human rights implications.

Potecting intellectual property rights helps enhance cross-border flow of information. However, it has different focuses compared with free flow of information in the trade of digital products. TRIPs, the Paris Convention for the Protection of Industrial Property, ${ }^{177}$ the Berne Convention for the Protection of Literary and Artistic Works ${ }^{178}$ and other international intellectual property conventions ensure national treatment of domestic and foreign intellectual property rights and their holders. ${ }^{179}$ However, they do not regulate market access, which is a major barrier for cross-border information flow. ${ }^{180}$

\section{Polycentric Direction}

The TPP enhances e-commerce regulation by creating a separate category for digital products transmitted online, strengthens mandatory rules and behind-the-border measures in consumer protections, and increases the level of liberalization in free flow of information. ${ }^{181}$ However, the U.S. has withdrawn from the TPP. The U.S.-South Korea and China-South Korea FTAs are the most recent FTAs concluded by each country. The following table is a summary of their differences and similarities.

Comparison between the China-South Korea FTA and the U.S.-South Korea FTA ${ }^{182}$

\footnotetext{
${ }^{172}$ E.g., art. 17.29 of the U.S.-Australia FTA, art. 16.9.22 of the U.S.-Singapore FTA, Art. 17.11.23 of the U.S.-Chile FTA, art. 18.9.30 of the U.S.-South Korea FTA, and Section J of Chapter 18 of the TPP.

${ }^{173}$ Introduction to the Intellectual Property Chapter of the TPP, https://medium.com/the-trans-pacificpartnership/intellectual-property-3479efdc7adf\#.182pjgqde (accessed 28 November 2016).

${ }_{174}$ IP law is technical-oriented and has limited human rights implications, see e.g., Liu (2016), pp. 14 16, who discusses E-commerce Law of China and on how foreign companies can protect their intellectual property rights.

${ }^{175}$ Art. 36 of Chinese Tort Law. Similar regulations can be found in Articles 3, 4, 6, 7, 8, 9 of Regulation of Several Questions on Applicable Law in Civil Cases of Online Information Transmission Infringement issued by the Supreme People's Court on November 26, 2012 and effective on January 1, 2013.

${ }^{176}$ Art. 36 of China Tort Law.

177 The Paris Convention for the Protection of Industrial Property, signed in Paris, France, on 20 March 1883, http://www.wipo.int/treaties/en/text.jsp?file id=288514 (accessed 15 July 2017).

178 The Berne Convention for the Protection of Literary and Artistic Works, signed on Berne, Switzerland, on Sept 9, 1886, http://www.wipo.int/treaties/en/text.jsp?file id=283698, (accessed 15 July 2017).

${ }^{179}$ Art. 3 of the WTO Agreement on Trade-related Intellectual Property Rights.

${ }^{180}$ See Block (2014), p. 694.

${ }^{181}$ See Section 4.

182 This chart is based upon discussions in Section 4 of this paper. In this chart, "yes" refers to compulsory obligations as opposed to best-efforts clauses, "no" refers to no provisions in the relevant treaty.
} 
Published Netherlands International Law Review volume 64, pages 309-337 (2017)

https://link.springer.com/article/10.1007/s40802-017-0094-1

\begin{tabular}{|c|c|c|}
\hline Clauses & The China-South Korea FTA & $\begin{array}{l}\text { The U.S.-South Korea } \\
\text { FTA }\end{array}$ \\
\hline Classification & No in FTA. & Yes. \\
\hline $\begin{array}{c}\text { Non-discriminative } \\
\text { Treatment }\end{array}$ & No in FTA. & Yes. \\
\hline $\begin{array}{c}\text { Fraudulent and } \\
\text { deceptive commercial } \\
\text { activities }\end{array}$ & $\begin{array}{c}\text { No in FTA. } \\
\text { Yes, in Chinese domestic law. }\end{array}$ & Best efforts clause. \\
\hline $\begin{array}{c}\text { Unsolicited commercial } \\
\text { spams }\end{array}$ & $\begin{array}{c}\text { No. } \\
\text { Yes, in Chinese domestic law. }\end{array}$ & No. \\
\hline $\begin{array}{c}\text { Personal information } \\
\text { and privacy }\end{array}$ & Best efforts clause. & Best efforts clause. \\
\hline $\begin{array}{l}\text { Principles on access to } \\
\text { and use of the Internet }\end{array}$ & No in FTA. & Best efforts clause. \\
\hline $\begin{array}{l}\text { Cross-border transfer of } \\
\text { electronic information }\end{array}$ & No in FTA. & Best efforts clause. \\
\hline Dispute resolution & No in FTA. & Yes. \\
\hline ISP safe harbor & $\begin{array}{l}\text { Best efforts clause in FTA. } \\
\text { Yes, in Chinese domestic law. }\end{array}$ & Yes. \\
\hline Localization & No. & No. \\
\hline Source code & No. & No. \\
\hline
\end{tabular}

As best-efforts clauses do not impose compulsory obligations upon member states, the ecommerce chapters of the China-South Korea FTA and the U.S.-South Korea FTA are not significantly different.

In the future, the e-commerce rules in China's FTAs may have three features. Firstly, China's FTAs with developed countries may define digital products as those transmitted online and provide national treatment and MFN treatment to products and their suppliers. These rules will assist China in circumventing the WTO law impasse and benefit Chinese internet enterprises. However, meanwhile, China will continue actively enacting and implementing e-commerce rules under the WTO framework. Secondly, China's FTAs may offer stronger consumer and privacy protection. These international commitments are supported by recent developments of Chinese domestic law discussed in Section 3.2. Thirdly, China will be very cautious to include free flow of information into FTAs due to its political concerns.

Even if the U.S. continues to push free flow of information by its future bilateral FTAs, their influence may be less pressing upon China in the near future. Because the TPP has twelve member states in the Asia Pacific, covering 40\% of the world GDP, it establishes a monocentric pattern. The impact of the TPP will be hard to displace through bilateral FTAs, ${ }^{183}$ such as the proposed U.S.-Japan FTA and the U.S.-Vietnam FTA.

${ }^{183}$ Hufbauer and Cimino-Isaacs (2015), p. 696. 


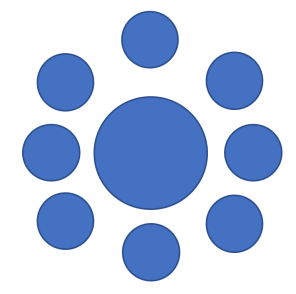

Picture one (Monocentric): The big circle refers to the TPP, which aims to set the $21^{\text {st }}$ century standard for e-commerce laws. The small ones refer to other FTAs in Asia Pacific.

\section{China's future FTAs,}

including the proposed Regional

Economic Comprehensive Partnership (RECP), ${ }^{184}$ may continue to avoid regulations of free flow of information and maintain the WTO approach to separate e-commerce and human rights. Bilateral FTAs concluded by the U.S. may promote free flow of information, which has potential human rights implications. This digital divide may split the development of international trade law for e-commerce. In the post-TPP era period, the making of international trade law for e-commerce in the Asia-Pacific will occur in a polycentric pattern. ${ }^{185}$ FTAs concluded by China and the U.S. respectively may converge in terms of classification and treatment of digital products and protection of consumers and privacy. However, they may openly conflict on regulation of free flow of information. In a polycentric pattern, systems of functionally overlapping international institutions may affect each other's operations. ${ }^{186}$ The different e-commerce regulation regime established by China, especially in the field of free flow of information, will compete with the U.S. regime to attract participants, gain trading volume or develop new strategies. ${ }^{187}$ The FTAs in the polycentric pattern are heterarchically ordered and none can impose their regulation upon the entire regime. ${ }^{188}$

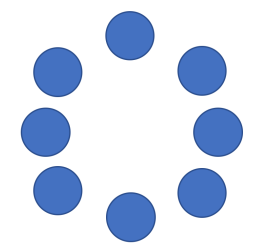

Picture two (polycentric): post-TPP era. The circles represent coexisting FTAs in Asia Pacific without a single comprehensive dominant agreement.

In a few industries, privately-owned Chinese enterprises have actively advocated their voice in international rule-making. E-commerce is one example. ${ }^{189}$ Jack Ma, Alibaba Group Executive Chairman and United Nations Assistant Secretary-General, is calling for the establishment of an Electronic World Trade Platform (“eWTP”) to help small to medium-

\footnotetext{
${ }^{184}$ One important difference between the RECP and the TPP is its purpose and aim because it does not aim to set the $21^{\text {st }}$ century standard for international trade law in Asia Pacific. In other words, the RECP can be described as contracts between member states while the TPP is law-making. Martin (2013), p. 31, who indicates that "the distinction between the various types of treaty is not one of legal effect but one of purpose and aim, and this is the only reason why we might like to describe some treaties as contracts and some as law-making."

${ }^{185}$ Polycentric governance or regime complexes is a theory developed in the 1980 s, see generally Ostrom et al. (1978); Naiki (2016), p. 132. This theory has been widely used in many fields of legal studies, international politics and international relation, e.g., see Kenneth (2014), pp. 57-88; Nii A. Addy et al. (2014), pp. 216-29; Bulkily et al. (2012), pp. 591-612; Mallard (2014), pp. 445-472; Ostrom (2010), p. 656; Murray (2007), pp. xii, 250; Kal and David (2004), pp. 277-309.

${ }^{186}$ Gehring and Faude (2013), pp. 120, 123.

${ }^{187}$ See Bluemel (2007), p. 2028.

${ }^{188}$ See Kuyper (2015), p. 320.

${ }^{189}$ Black (2008), p. 137-38, who indicates that "[Polycentric] regimes are those in which the state is not the sole locus of authority".
} 
sized enterprises ("SMEs"), developing countries and young people to enter the global market and join the global economy. ${ }^{190}$ eWTP would link local, regional, national and international e-commerce internet platforms. ${ }^{191}$ It facilitates SMEs compliance with various government regulations on products, customs procedures and provides better access to logistics and financing. ${ }^{192}$ According to Jack Ma, the eWTP is a logical and natural complement to the WTO but it is driven by businesses with support from governments. ${ }^{193}$ Jack Ma has vigorously advocated for eWTP in Business 20 SME Development Taskforce, ${ }^{194}$ the G20 and Boao Forum for Asia Annual Conference 2016. ${ }^{195}$ The eWTP has been included in the G20 Leaders' Communiqué published after the 2016 Hangzhou Summit. ${ }^{196}$ Currently, the eWTP initiative lacks details so it is difficult to predict its potential. Nevertheless, ecommerce rules proposed by Chinese enterprises may possibly be commercially-oriented. The rules will protect consumer and privacy but will not touch upon free flow of information which may have human rights connotations. A similar approach seems to be adopted by Facebook. According to the New York Times, in 2016, Facebook quietly built software to censor news feeds in specific geographic areas to prepare the company for entry into China. ${ }^{197}$ In a polycentric system, private entities develop informal law ${ }^{198}$ that impacts the development of international trade law for digital products. China is one of the largest and most lucrative markets for all e-commerce companies. Private entities are profit-making and may be publicly held. The market power may allow them to promote free flow of information while carving out human rights implications. ${ }^{199}$

\footnotetext{
${ }^{190}$ Fact Sheet Electronic World Trade Platform, http://www.alizila.com/wpcontent/uploads/2016/09/eWTP.pdf?x95431 (accessed 22 May 2017).

${ }^{191}$ Ibid.

${ }^{192}$ Ibid.

${ }^{193}$ WTO Director-General Welcomes Jack Ma's eWTP Proposal, http://en.people.cn/n3/2016/0907/c90000-9112090.html (accessed 22 May 2017).

${ }^{194}$ Electronic World Trade Platform (eWTP) Should Become a Key Policy Recommendation for G20, http://www.chinaeu.eu/electronic-world-trade-platform-ewtp-should-become-a-key-policyrecommendation-for-g20/ (accessed 22 May 2017). The Business 20 (B20) provides a significant platform for the international business community to participate in global economic governance and international economic and trade regulation, for more information about Business 20, see http://en.b20-china.org/about/68 (accessed 22 May 2017).

${ }^{195}$ Boao Forum Supports Jack Ma, The World Needs eWTP, http://yd.sina.cn/article/cj/detailifxqsxic3154112.d.html (accessed 22 May 2017).

${ }^{196}$ Para 38 of the G20 Leaders' Communique. Jack Ma's eWTP Proposal Included in G 20

Communique, http://www.shanghaidaily.com/business/Jack-Mas-eWTP-proposal-included-in-G20communique/shdaily.shtml (accessed 22 May 2017).

${ }^{197}$ Pui-Wing Tam (2016).

${ }^{198}$ Berman (2015), pp. 73-74, who argues that being of a technical or scientific nature, states may prefer non-binding informal rules developed by private entities as these entities have relevant expertise and their rules more flexible and adaptable than treaties.

${ }^{199}$ See Prenkert and Shackelford (2014), pp. 467-69, who indicate that "[t]he likelihood that corporate responsibility for human rights could be enshrined in some sort of comprehensive and binding instrument of international law or treaty was nil.
} 


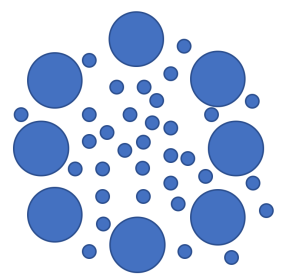

Picture Three (further polycentric): joint rule-making by public and private bodies in post-TPP era. The big circles refer to FTAs. The small circles refer to ecommerce rules made by non-governmental bodies, such as NGOs and enterprises.

As Professor William W. Burke-White argued, "new pluralism is emerging". ${ }^{200}$ In the polycentric pattern, the pluralism is not only of governments but also of non-governmental entities. ${ }^{201}$ E-commerce rules supported by China and its enterprises may accept classification of digital products and provide better consumer and privacy protections, moving towards its American counterparts. However, they will be very cautious to incorporate rights for free flow of information, or alternatively they may support free flow of information devoid of any human rights implications. The abandonment of the TPP may give China an opportunity to reassert its pre-eminence in the development of international trade law for e-commerce.

${ }^{200}$ Burke-White (2015), p. 79.

${ }^{201}$ Pauwelyn et al. (2014), pp. 738, 742. 


\section{References}

Addy N A et al. (2014) Whole-of-society approach for public health policymaking: a case study of polycentric governance from Quebec, Canada. Ann. N. Y. Acad. Sci. 1331: 216-229

Bauer M et al. (2014) The Costs of data localization: friendly fire on economic recovery, p. 4, http://www.ecipe.org/app/uploads/2014/12/OCC32014 1.pdf. Accessed 21 May 2017.

Berman A (2015) Is there a stagnation in international law, ASIL Proceedings 109: 73-74.

Bernier I (2004) A UNESCO international convention on cultural diversity. In: Graber C B, Girsberger M and Nerova M (eds) Free trade versus cultural diversity: WTO negotiations in the field of audiovisual services. Schulthess, Zurich, pp 65-76.

Bieron B and Ahmed U (2012) Regulating E-commerce through international policy: understanding the international trade law issues of E-commerce. Journal of World Trade 46: 556.

Black J (2008) Constructing and contesting legitimacy and accountability in polycentric regulatory regimes. Reg \& Governance 2: 137-38.

Block R (2014) Comment: market access and national treatment in China--electronic payment services: an illustration of the structural and interpretive problems in GATS, Chic. J. Int. Law 14: 694 .

Bluemel E B (2007) Unraveling the global warming regime complex: competitive entrophy in the regulation of the global public good. University of Pennsylvania Law Review 155: 2028.

Brenkert G (2009) Google, human rights, and moral compromise, J. Bus. Ethics 85: 454.

Broude T (2010) It's easily done: the China intellectual property rights enforcement dispute and the freedom of expression, J. World Intell. Prop. 13: 661.

Bulkily et al. (2012) Governing climate change transnationally: assessing the evidence from a databased of sixty initiatives. Environmental and Planning C: Government and Policy 30: 591-612.

Burri-Nenova M (2010) Trade and culture in international law: paths to (re)conciliation. Journal of World Trade 44: 51.

Burri-Nenova M (2009) Trade versus culture in the digital environment: An old conflict in need of a new definition, J. Int. Econ. Law 12: 40.

Burke-White W W (2015) Power shifts in international law: structural realignment and substantive pluralism, Harv Intl J 56: 79.

Butcher B and Ip M (2007) Are Chinese consumers winners or losers under WTO membership?. Macquarie J. Bus. L. 4: 72.

Carey N (2014) Taxing E-commerce: an abundance of constraints. Rutgers Computer and Technology Law Journal 40: 156-271.

Ciocchetti C (2007) E-Commerce and information privacy: privacy policies as personal information protectors. American Business Law Journal 44: 71.

Chander A and Lê U P (2014) Breaking the Web: data localization vs. the global Internet, Working Paper 2014-1, California International Law Center, http://ssrn.com/abstract=2407858. Accessed 28 November 2016.

Cho S Y et al (September 2016) MERS-CoV outbreak following a single patient exposure in an emergency room in South Korea: An epidemiological outbreak study. The Lancet 388: 9941001.

Clark L and Berners-Lee T (2014) We need to re-decentralise the web. www.wired.co.uk/news/archive/2014-02/06/tim-berners-lee-reclaim-the-web. Accessed 28 November 2016. 
Delimatsis P (2011) Protecting public morals in a digital age: revisiting the WTO rulings on U.S. - Gambling and China - Publications and Audiovisual Products. J. Int. Econ. Law 14: 257293.

Gao H (2011) Google's China problem: a case study on trade, technology and human rights under the GATS. Asian Journal of WTO and International Health Law 6: 356-357.

Gehring T and Faude B (2013) The dynamics of regime complexes: microfoundations and systemic effects. Glob. Gov. 19: 120, 123.

Hufbauer G C and Cimino-Isaacs C (2015) How will TPP and TTIP change the WTO system?. J. Int. Econ. Law 18: 696.

Jackson J H (2006) Sovereignty, the WTO, and changing fundamentals of international law. Cambridge: Cambridge University Press.

Kal R and David V (2004) The regime complex for plant genetic resources, International Organization 58: 277-309.

Kelsey J (2013) The Trans-Pacific Partnership Agreement: a gold-plated gift to the global tobacco industry. Am. J. L. \& Med. 39: 241.

Kenneth A (2014), Strengthening the transnational regime complex for climate change. Transnational Environmental Law 3: 57-88

King N J and Raja V T (2013) What do they really know about me in the cloud? a comparative law perspective on protecting privacy and security of sensitive consumer data. Am. Bus. Law J. 50: 413-482.

Knight P (2011), Seeds fallen in stony places: the failure of DMCA safe harbor provisions imposed by the Australia-United States Free Trade Agreement, LANDSLIDE 3.6: 38.

Kuyper J (2015) Deliberative capacity in the intellectual property rights regime complex. Critical Policy Studies 9: 320.

Land M (2013) Toward an international law of the Internet. Harvard International Law Journal 54: 401.

Lee J A and Liu C Y (2012) Forbidden city enclosed by the great firewall: the law and power of Internet filtering in China, Minn. J. L. Sci. \&Tech. 13: 128.

Lewis M K (2011) Trans-Pacific Partnership: new paradigm of wolf in sheep's clothing. Boston College International and Comparative Law Review 34: 32-33.

Liu Y P (2016), E-Commerce intellectual property rights protection in China, Intellect. Prop. Technol. Law J. 28: 14-16.

Low P and Mattoo A (2008) Is there a better way? alternative approaches to liberalization under the GATS, p. 22, http://tradeinservices.mofcom.gov.cn/upload/2008/08/18/1219022407969_58106.pdf. Accessed May 17, 2017.

Luo K (2016) E-Commerce laws and practices in China. Ariz. J. Int. Comp. Law 33: 219-228.

MacDonald D and Streatfeild C (2014) Personal data privacy and the WTO. Hous. J. Int'1 L. 36: 638.

Mallard G (2014) Crafting the nuclear regime complex (1950-1975): dynamics of harmonization of opaque treaty rules. Eur. J. Int. Law 25: 445-472

Matthias Bauer et al (2014). The costs of data localisation: friendly fire on economic recovery, European Centre for International Political Economy, No. 3/2014, p. 2.

Martin D (2013) Textbook on International Law. $7^{\text {th }}$ ed. Oxford: Oxford University Press.

McCauley D (2016) Inside the world's biggest shopping event, http://www.news.com.au/finance/business/retail/inside-the-worlds-biggest-shoppingevent/news-story/ddf8e2794db542d33018002747ac70ae. Accessed 30 November 2016.

Ming C (2016) Singles' Day: Alibaba smashes records at world's largest online shopping event, http://www.cnbc.com/2016/11/11/singles-day-news-alibaba-poised-to-smash-records-atworlds-largest-online-shopping-event.html. Accessed 30 November 2016. 
Mishra N (2017) The role of the Trans-Pacific Partnership Agreement in the Internet ecosystem: uneasy liaison or synergistic alliance?. J. Int. Econ. Law 20: 55-56.

Mozur P (2016) The U.S. added China's Internet controls to list of trade barriers, https://www.nytimes.com/2016/04/08/business/international/china-internet-controlsus.html? r=0. Accessed 10 March 2017.

Murray A W (2007) The regulation of cyberspace: control in the online environment. Abingdon: Routledge.

Naiki Y (2016) Trade and bioenergy: explaining and assessing the regime complex for sustainable bioenergy, Eur. J. Int. Law 27: 132.

Ostrom E (2010) Beyond markets and states: polycentric governance of complex economic systems. Am. Econ. Rev. 10: 656.

Ostrom E et al. (1978) Patterns of metropolitan policing. Ballinger Publishing Company.

Pauwelyn J (2010) Case note, squaring free trade in culture with Chinese censorship: the WTO Appellate Body report on China-Audiovisuals. Melb. J. Int'1 Law 11: 132-33.

Pauwelyn J, Wessel R and Wouters J (2014) When structures become shackles: stagnation and dynamics in international lawmaking. The European Journal of International Law 25: 738, 742.

Prenkert J D and Shackelford S J (2014) Business, human rights, and the promise of polycentricity. Vand. J. Transnat'1 L. 47: 467-69.

Qin J Y (2011) Pushing the limits of global governance: trading rights, censorship and WTO jurisprudence-A commentary on the China-Publications case, Chinese J. Int'l L. 10: 271.

Qi Y (2016) Import duties relating to cross-border E-commerce in a Chinese context. Ariz. J. Int. Comp. Law 33: 263-273.

Reinsch R (2005) E-Commerce: managing the legal risks. Managerial Law 47: 168.

Seong M W (2016) Microevolution of outbreak-associated Middle East respiratory syndrome coronavirus, South Korea, 2015. Emerg Infect Dis. 22: 328-29.

Simões F D (2017) Amicus curiae in the Trans-Pacific Partnership. Am. Bus. Law J. 54: 165-166.

Sink J et al. (2017) China eager to fill political vacuum created by Trump's TPP withdrawal, https://www.bloomberg.com/politics/articles/2017-01-23/trump-s-withdrawal-from-asiatrade-deal-viewed-as-boon-for-china . Accessed 10 March 2017; Gracie C (2017), U.S. leaving TPP: a great news day for China, http://www.bbc.com/news/world-asia-china38060980. Accessed 10 March 2017.

Siqueira P (2014) It's in the way that you use it: revisiting trade and human rights in the case of online censorship. Sw. J. Int'1 L. 20: 39-60

Shackelford S and Craig A (2014) Beyond the new "digital divide": analyzing the evolving role of national governments in Internet governance and enhancing cybersecurity. Stanford Journal of International Law 50: 157-64.

Sonia R (2014) Are consumer-oriented rules the new frontier of trade liberalization. Harvard International Law Journal 55: 362-63.

Stevenson C (2007) Breaching the great firewall: China's Internet censorship and the quest for freedom of expression in a connected world. B.C. Int'l \& Comp. L. Rev. 30: 537.

Tam P W (2016) Daily report: Facebook courts China with censoring software, https://www.nytimes.com/2016/11/23/technology/daily-report-facebook-courts-china-withcensoring-

software.html?rref=collection\%2Ftimestopic\%2FInternet $\% 20$ Censorship $\% 20 \mathrm{in} \% 20 \mathrm{China} \& \mathrm{a}$ ction $=$ click\&contentCollection $=$ world\&region=stream\&module=stream unit\&version=latest \&contentPlacement=1\&pgtype $=$ collection. Accessed 22 May 2017.

Thurman S D (1973) The right of access to information from the government, Oceania Publications. 
Voon T (2006) UNESCO and the WTO: a clash of cultures?. International and Comparative Law Quarterly 55: 635-652

Weber R H (2015) Digital trade and E-commerce: challenges and opportunities of the AsiaPacific regionalism. Asian J WTO Int'1 Health Pol' 10: 324.

Wu T (2006) The world trade law of censorship and Internet filtering. Chi. J. Int'1 L. 7: 280.

Wunsch-Vincent S (2006a) The Internet, cross border trade in services, and the GATS: lessons from U.S.-Gambling. World Trade Review 5(3): 323-55.

Wunsch-Vincent S (2006b) The WTO, the Internet and trade in digital products: EC-U.S. perspectives. Bloomsbury.

Yan W (2005) The electronic signatures law: China's first national E-commerce legislation. Intellectual Property \& Technology Law Journal 17: 6-10.

Yong H (2016) Three features of China's Internet legislation. 48: 2-3.

Zhang T (2015) Understanding the Chinese Internet: why do challenges exist?, https://www.aiia.com.au/documents/event-presentations/2015/national/internet-challengessolutions-when-doing-business-in-china.pdf. Accessed 28 November 2016.

Zheng H P (2013) Regulating the Internet: China's law and practice, Beijing Law Rev. 4: 37-41. 